\title{
MYTHOLOGICAL SYMBOLS FROM THE THRACIAN ME- GALITHIC SANCTUARIES, CHRISTIAN AND MUSLIM SACRED PLACES ON THE BALKANS
}

\section{SÍMBOLOS MITOLÓGICOS DE LOS SANTUARIOS ME- GALÍTICOS TRACIOS, Y DE LOS SANTUARIOS CRISTIA- NOS Y MUSULMANES EN LOS BALCANES}

\author{
Vassil Markov ${ }^{1}$ \\ The South-West University (Bulgaria)
}

\begin{abstract}
The ancient Thracian megalithic and stone-hewn sacred places are full of symbols closely connected with the Thracian mythology and ancient cult practices which were typical for this area. Among them the most numerous are the huge stone-hewn human footprints, which in Bulgarian folklore were regarded as the footprints of the hero Krali Marko, who was thought of as the guardian of the people in Bulgaria. In the contemporary science studying Thrace he is believed to have been the folklore successor of the Thracian Dionysus.

Marking the sacred place with a stone-hewn footstep altar of the hero was authentic evidence for the believers in ancient times that the god had been there in primordial mythological times. In this way, through the contact with the divine, the monumental rock turns into sacred and the place turns into a sanctuary. The raw becomes boiled, Nature becomes culture.

With the establishment of Christianity as the sole religion in the Roman Empire since the 4th century, some of the Thracian megalithic sanctuaries have been abandoned. Others have been Christianized. Later, others in the Middle Ages were converted into Islamic sacred places. In this way they became permanently sacred places on the Balkans. Part of the signs-symbols in them have a new meaning in the spirit of the new religions.
\end{abstract}

Key words: anthropology; history of culture; religion; mythology; archaeology;

Resumen: Los antiguos espacios sagrados tracios megaliticos y dolménicos están llenos de símbolos estrechamente conectados con la mitología de los tracios y las anti-

[1] CV: Professor, Doctor of Science Vasil Markov is a lecturer of ancient cultures in the South-West University "Neofit Rilski», Department of Cultural Studies, Bulgaria. He is Director of the University Research Centre for European and ancient Easterly Mediterranean cultures. Professor Markov is a researcher of the megalithic culture in the Balkans and Anatolia. e-mail: ve22@abv.bg 
guas prácticas de culto, típicas de esta área. Las más numerosas son las grandes tallas en piedra de huellas que el folclore búlgaro considera las del heroe Krali Marko, considerado como el guardia de las personas en Bulgaria. En la ciencia contemporánea que estudia la Tracia se cree que él ha sido el sucesor del Dionisio tracio.

Hacer un lugar sagrado con una piedra tallada de su huella como altar del héroe, fue realmente una autentica prueba para los creyentes de la antiguedad, de que Dios habia estado allí en la primogenia época mitológica. En este sentido, mediante el contacto con lo divino, la roca monumental se convierte en sagrada y el lugar se convierte en un santuario. Lo crudo se convierte en cocido, la Naturaleza se convierte en cultura.

Con el establecimiento de la Cristianidad como única religion en el Imperio Romano desde el siglo IV, algunos de los santuarios megalíticos de los Tracios fueron abandonados, aunque otros fueron cristianizados. Después, en la Edad Media, otros fueron apropiados como espacio sagrado Islámico. De esta manera, permanecen como espacios sagrados en los Balcanes. Parte de los signos-símbolos que hay en ellos han adquirido nuevos significados debido al espiritu de las nuevas religiones.

Palabras claves: Antrología; historia de la cultura; religión; mitología; arqueología;

The ancient Thracian megalithic and stone-hewn sacred places are full of symbols closely connected with the Thracian mythology and ancient cult practices which were typical for this area. In most cases those are monumental and silhouette-like images of lions and people, stone mushrooms, circles hewn into the rock, human and animal footprints, altars, etc. They are often interpreted as mythological symbols or a divine epiphany.

Among them the most numerous are the huge stone-hewn human footprints, which in Bulgarian folklore were regarded as the footprints of the hero Krali Marko, who was thought of as the guardian of the people in Bulgaria. In the contemporary science studying Thrace he is believed to have been the folklore successor of the Thracian Dionysus. Even more numerous are the heart-shape and circular stone-hewn altars, which Bulgarian folklore beliefs attribute to the dog and the horse of this mighty horse-riding hero ${ }^{2}$.

If we try to reconstruct the image of the hero from the footprints he has left on the stone, we will see a giant descendant of the pagan deities from the East standing on the symbol of the cosmic mountain - the rock. In size he is a god-like giant from the mythology, analogous to the huge horseman on the votive tablets with the Thracian horseman dating from the Thracian-Roman age. There the Thracian horseman is presented typically for the East way like a giant followed by a dog and approaching a stone altar.

[2] Markov, V. Cultural Heritage and Succession. Heritage of Ancient Pagan Sacred Places in Bulgarian Folk Culture. Blagoevgrad: Neofit Rilski University Press, 2007, p. 123-144 
Marking the sacred place with a stone-hewn footstep altar of the hero was authentic evidence for the believers in ancient times that the god had been there in primordial mythological times. In this way through the contact with the holy character the profane monumental rock turns into a sacred one and the place turns into a sanctuary. The raw becomes boiled, Nature becomes culture.

In fact with the help of the signs-symbols on the megalithic sanctuaries it was shown and suggested what we can find as a figurative code on the stone votive tablets with the Thracian horseman. This image is an archaic one. It dated from the late Bronze Age and the early Iron Age. It has gone through the Classical, Hellenistic and Roman periods, when the images of the Thracian horseman appeared in the formal art of the Thracians undergoing Greek and Roman influence. It is indicative that exactly the most archaic image of the horseman-hero connected with the ancient Thracian megalithic sanctuaries has been kept as folklore heritage. This can be successfully explained with the proposition made by Ivan Venedikov that the more archaic and conservative a mythological belief is, the longer it exists ${ }^{3}$.

Through the footprint as a sign-symbol the myth was permanently «recorded» on the monumental rock phenomena including it in the cultural area. The natural codes turned into symbols, which started suggesting and maintaining the myth in people's minds. In this way the ancient Thracian myth was so strongly inscribed on the landscape of the Balkans and in the mind of the people inhabiting the area that it has survived for centuries. Of course, it has been influenced by the passions, aspirations and cultural specific character of the following ethnic groups that have inherited the ancient culture. As a result of those processes it has reached our time transformed by the same or similar rules according to which some of the ancient myths have been transformed into fairy tales ${ }^{4}$.

A special attention should be paid to the traditional healing practices that have been kept in Bulgarian folk culture. Those healing practices were performed with rain water from the stone-hewn footprints-altars of the hero Krali Marko and of his winged horse, Sharko. In a number of cases this water is considered the sacred one, which brings health and fertility. By ritual washing and drinking it heals eye and skin diseases, women's infertility, child diseases, etc. A typical example of those practices are the ones from Govedar kamen (stone), near the city of Shtip in Macedonia ${ }^{5}$,

[3] Venedikov, Iv. The Birth of the Gods, Sofia,1992, p. 334

[4] Propp, Vl.Y. Historical Roots of the Magic Tales. Sofia, 1992, c.45

[5] Vrajinovski, T. Folk Mythology of the Macedonians. Skopje-Prilep, 1998, vol. I, p. 108-109 
Markov's stone near the village of Dolen, Blagoevgrad region ${ }^{6}$, Markov's stone in Strandzha mountain ${ }^{7}$, etc.

In this mythological belief probably, an artifact from the ancient mythology has been preserved where rain water is sent by the Storm God to fertilize the Mother Earth ${ }^{8}$. Moreover, it could be assumed that the healing and magical powers of the water are due to the contact of the water with the rock and the footprint left on it by the holy character in ancient Thrace. Indicative of this is the well-known traditional practice in Bulgaria to overturn the footprints of the ill, which were outlined on the ground with a knife. This overturning was accompanied by an oral invocation for help from God's mother ${ }^{9}$. It is obvious that it was an imitational magic spell aiming at overturning the state of the ill person, who was represented by their footprints. Thus it can be considered that the footprint symbolizes the nature of the human being and respectively of the mythological character in the ancient Thracian sacred places. A vivid example is the parallel with the gold-plated limbs of the Thracian horseman from Letnitsa treasure, as well as the gold-plated feet, hands/gloves from the antique necropolis in Trebnishte, Macedonia ${ }^{10}$.

A very popular fairy tale in Bulgaria, "A Brother Deer», has preserved the old mythological belief about the magical transforming power of the water in the animals' footprint. If a person drinks water from such a footprint, they turn into the animal which has left that footprint ${ }^{11}$.

The songs and legends in the folklore of Bulgaria and Serbia present Krali Marko's horse as huge and winged and "where it steps water springs appear». This mythological belief has a good counterpart in the springs made by the steps of the horse Pegasus ridden by the hero Bellerophon in ancient Greek mythology. An example for that is that the water in one of those springs had magical purifying powers ${ }^{12}$.

[6] Markov, V. God,s Signs. Blagoevgrad: Neofit Rilski University Press, 2002, p.56-137

[7] Fol, C. «The sacred space». in: Myth, history, folklore. Vol. III, Sofia, 1988, p. 8-9

[8] Venedikov, Iv. Op. cit., p. 112-159

[9] Shavarova, P. «Whether the traditional healing practices in the Strandja Mountain are traditional today?»- Announcements of the Museums in Southeastern Bulgaria. Vol. 20, Bourgas, 2003, p. 133.

[10] Fol, Al. Thracian Dionysus. Book Two. Sabazius. Sofia: Kliment Ohridski University Press, 1994.p. 59-62; Avramova, M. «The Magic Sign» in- Seminarium Thracicum, vol. 6. Sofia: BAS, Institute of Thracology, 2004, p. 9-23.; Koneva, L. "The Necropolis at Trebenishte - studies and problems.» in Problems of Art, 1994, vol. 4, p. 8-12.

[11] Daskalova-Perkovska, L., Dobreva, D., Kotzeva, J., Mitseva, E. Bulgarian folk tales. Catalog. Sofia: Kliment Ohridski University Press, 1994, p. 82

[12] Paus II. 31.9 
With the establishment of Christianity as the sole religion in the Roman Empire since the $4^{\text {th }}$ century, some of the Thracian megalithic sanctuaries have been abandoned. Others have been Christianized. Later, in the Middle Ages, others were converted to Islam. In this way they became permanently sacred places on the Balkans ${ }^{13}$. Part of the signs-symbols in them, have a new meaning in the spirit of the new subsequent religions. For example, the footprints-altars in the Thracian megalithic sacred places were presented as the footprints of God, Virgin Mary, Ivan of Rila, the Holy Ghost, the Alevi saint Demir Baba, and others ${ }^{14}$. The relationship between the folklore artifacts of the old religion of the Thracians and the new Christian religion were different. For instance, the Thracian megalithic sanctuary at Krastilski vrah (mountain), Blagoevgrad region, was turned into a Christian churchyard devoted to the Ascension of Christ. Through the canonical Christian ritual this sacred Christian place has been honored till nowadays by the population of the nearby villages. Simultaneously the population always visits the Thracian stone-hewn altars, due to the legend of the mighty horseman, Krali Marko, which has been passed from generation to generation. He flew on the back of his horse from Pirin Mountain over the valley of the river Struma. Its forelegs dug the two deep altars into the rock. In such a way this place became sacred in primordial mythological times.

In the megalithic sanctuary of St. George Rock near the village of Bachevo, Blagoevgrad region, the horseman has turned into the Christian saint George. After the $14^{\text {th }}$ century the image of this saint on the Balkans resembles amazingly the Thracian horseman from the Thracian-Roman period. According to the local legend the saint went through the area and the footprints of his horse can be seen on the rock. Today the Thracian sacred place is marked by a small chapel. His holiday, $6^{\text {th }}$ May, is celebrated here and the people go through the ancient monumental trilithon (rock arch) hoping that it will bring them health and fertility. In order to pay for the health and prosperity given to them by the saint, they leave coins in the stone-hewn footprints-altars.

The best example is in the Thracian royal sanctuary of Kamen Rid in the Historical-archaeological reserve of Sboryanovo, North-East Bulgaria.The ancient sacred place is part of the royal ritual complex in the capital of the Thracian Gets - Dausdava/Helis. In the High Middle Ages, this was succeeded by a Christian monastery devoted to Saint George, and in the

[13] Eliade, M. History of Religious Beliefs and Ideas. T.I. From the Stone Age to the Eleusinian Mysteries. Sofia, 1997, p. 301-368

[14] Markov, V. «Cultural Heritage and Succession. Heritage of Ancient Pagan Sacred Places» in Bulgarian Folk Culture. Blagoevgrad: Neofit Rilski University Press, 2007, p. 123-210 
Late Middle Ages it became Islamic and was turned into a sepulchre of the Alevi hero and saint Demir Baba - the Iron Father. Today the Shiites say that the Thracian altars hewn into the rock plateau of Kamen Rid are the footprints of their saint. They also claim that they can see the footprints of his dog and horse and the rut of his cart. All of them are in fact altars hewn into the rock in Thracian times. For them they are evidence that in the past, in primordial mythological times, the hero Demir Baba was here; he created all the sacred places and he accomplished his feats here. What is more, on Hidrellez / St. George's Day, as part of the rituals for health, fertility and healing women's infertility, the young women-Shiites try to find the footprints of the saint. They take off their shoes and step in the footprints. It is a myth-ritual activity which could be interpreted only as a union with the ancient mythological character, who was succeeded by the folklore image of the Alevi saint Demir Baba.

In conclusion I would like to add one touch to Mircha Eliade's thesis, which I like very much, that «Sacred places are everlasting»: «The sacred places are everlasting also because of the new meaning that has been given for centuries to the everlasting symbols in them» 